IRA-International Journal of Applied Sciences ISSN 2455-4499; Vol.05, Issue 02 (2016)

Institute of Research Advances

Pg. no. 91-109

http://research-advances.org/index.php/IRAJAS

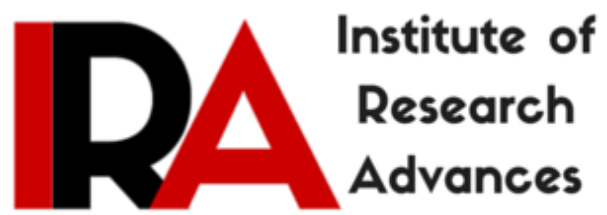

\title{
DNA Barcoding and Intra Species Analysis of the Ember Parrot Fish Scarus Rubroviolaceus using mtCO1
}

\author{
Chandan Tiwary ${ }^{1}$, M.A.Badhul Haq ${ }^{1}$, S.Vaitheeswari ${ }^{1}$, M.Kalaiselvi ${ }^{1}$, Mohammad \\ Nurul Azim Sikder ${ }^{2}$ and Wah Wah Min ${ }^{3}$ \\ ${ }^{1}$ Faculty of Marine Sciences, CAS in Marine Biology, \\ Annamalai University, Parangipettai - 608502, India. \\ ${ }^{2}$ Institute of Marine Sciences and Fisheries, \\ University Of Chittagong, Chittagong-4331, Bangladesh. \\ ${ }^{3}$ Department of Zoology, University of Yangon, Myanmar.
}

Type of Review: Peer Reviewed.

DOI: http://dx.doi.org/10.21013/jas.v5.n2.p5

\section{How to cite this paper:}

Tiwary, C., Haq, M., Vaitheeswari, S., Kalaiselvi, M., Sikder, M., \& Min, W. (2016). DNA Barcoding and Intra Species Analysis of the Ember Parrot Fish Scarus Rubroviolaceus using mtCO1. IRA-International Journal of Applied Sciences (ISSN 2455-4499), 5(2), 91-109. doi:http://dx.doi.org/10.21013/jas.v5.n2.p5

(C) Institute of Research Advances

\section{(cc) EY-NC}

This work is licensed under a Creative Commons Attribution-Non Commercial 4.0 International License subject to proper citation to the publication source of the work.

Disclaimer: The scholarly papers as reviewed and published by the Institute of Research Advances (IRA) are the views and opinions of their respective authors and are not the views or opinions of the IRA. The IRA disclaims of any harm or loss caused due to the published content to any party. 


\section{ABSTRACT}

In this study S.rubroviolaceus form very ancient family group Scorpaenidae with structurally diverse group of subphylum Vertebrata was collected form from parangipettai (MAB06)for species identification with inter specific variation among barcoding region sequenceing cytochrome oxidase subunit I (COI) gene comparing with Australia (EF609452), Tonga (FJ584082), South Africa (GU805008), Iran (HQ149928). The intraspecific variation analysis in NCBI screend for COI sequence form different geographical regions results $99 \%$ to $100 \%$ identity. BOLD's identification engine shows $99.68 \%$ to $100 \%$ similar of 20 specimens with conformation of COI species database tree that S.rubroviolaceus belongs to order Carangidae. The molar concentration of nucleotides in the COI region profiling barcoding valuates that high in thymine content are similar in all the samples, Cytosine as second predominant and guanine as least molar concentration. A helical wheel is ploted to illustrate the properties of alpha helices in proteins. Multiple sequence alignments for DNA sequences similarities query were analysed with Clustal W from EMBL tools.

Keywords: Interspecific variation, barcode, cytochrome oxidase, Scarus rubroviolaceus

\section{Introduction}

As mostly biological research carrying species diagnoses, taxonomic expertise is confusing. The way was made by the construction of barcodes as taxon validating based on $\mathrm{DNA}^{1}$. An extricating method for species identification, and can consistently proclaim the unknown species to known, also denoting potential mystrious species and genetically distant populations ${ }^{2}$. It was constructed under mitochondrial gene cytochrome $c$ oxidase I (COI) as kernel part for animals global bioidentification system $^{1}$ brought this breakthrough identification with mitochondrial genome and introduce the name DNA barcoding. Reasons for choosing mitochondrial (mtDNA) over nuclear DNA include uniparental inheritance (in a majority of animal phyla), high evolutionary rate, lack of introns, large copy numbers in every cell, and limited recombination. As mitochondrial DNA has uniparental inheritance (mainly in animal phyla), evolution rate, lack of introns, large copy numbers in each cells and limited recombination". The term "DNA barcode" was projected to imply that the characteristics of nucleotide sequences can be used to indicate a species is similarly as like the 11-digit Universal Product Codes in labeling retail products ${ }^{4}$. The DNA barcode project was initially conceived as a standard system for fast and accurate identification of animal species. Its scope is now that of all eukaryotic species ${ }^{5}$. The DNA barcode itself consists of a 648 bp region 58-705 from the 50-end of the cytochrome c oxidase 1 (COI) gene using the mouse mitochondrial genome as a reference ${ }^{6}$. It is based on the postulate that every species will most likely have a unique DNA barcode (indeed there are 4650 possible ATGC-combinations compared to an estimated 10 million species remaining to be discovered ${ }^{7}$ and that genetic variation between species exceeds variation within species ${ }^{1}$. The efficiency of species identification by molecular methods is judged by the levels of intraspecific homogeneity and interspecific heterogenenity displayed by the intended method ${ }^{8,9}$. Mitochondrial COI gene, as an attractive "species barcode", its high efficiency in species identification has been reported in Australia marine fishes ${ }^{10}$, Canadian freshwater fishes ${ }^{11}$ and ornamental fishes in the market of North America ${ }^{12}$.

Redlip Parrotfish is the common name of S.rubroviolaceus which occurs in seaward reefs. Usually over rocky or coral substrates, at boulder-strewn slopes at the base of high-island cliffs where it may occur in large schools. S.rubroviolaceus comes under subfamily Scarinae. The Scarini was under the family Labridae ${ }^{13}$. The Chlororus and Scarus are different monophyletic lineages ${ }^{14}$. While comparing the species in pacific and Indian ocean there is no absolute conformation for morphological differences but has genetic breaks between them ${ }^{15}$. Scarus rubroviolaceus and S. psittaccus is high in central Indo-Pacific population and has genetic divergence found at the periphery of each species range ${ }^{16,17}$. Only few studies are made in this fish merely based on its prominence in recreational, artisanal and commercial fisheries 
throughout its distribution ${ }^{18,19,20,21,22}$. The association between diversification and evolutionary innovations has been well documented and tested in studies of taxonomic richness but the impact that such innovations have on the diversity of form and functions are not well understood ${ }^{23}$.

Basically Parrotfishes consume algaes associated in the coral reef and those fishes are bioeroders that makes useful for healty reef ecosystem in the tropics ${ }^{24,25,26}$. S.rubroviolaceus as coral associated fishes, for fisheries and tourisum these fishes are economically valuble ${ }^{27,19,20}$. All parrotfishes are sequential protogynous hermaphrodites which exposes two colour phase ${ }^{28}$. Fish with essentially females having small male parts is Initial phase (IP) and only male without female is the terminal phase (TP $)^{28}$. In Hawaii areas Spawning in parrotfishes contineouses for whole year and peaks up in summer months form May to July ${ }^{30,29}$ and species may migrates to certain places for spawning ${ }^{30} .50 \%$ of S.rubroviolaceus are immature upto 13.5 inches fork length growth In Hawwaii islands ${ }^{31}$.

This species is fished in some parts of its range where destructive fishing practices and habitat destruction are prevalent. It is heavily fished in the northern Solomon Islands with evidence of a decline in mean size and numbers of this species in the markets from 2004-2006. It is the second or third most important species in the parrotfish fishery in 2004, but by 2006 the importance of this species in the fishery had declined ${ }^{15}$. It is a component of subsistence fisheries and is heavily fished in parts of its range. There have been indications of localized population declines in Indonesia, Philippines and the Solomon Islands. It is found in a number of marine reserves and in remote localities. It is therefore listed as Least Concern. Although there are numerous marine reserves in areas where this species is heavily fished (Coral Triangle Region), most reserves are not very well managed. However, in well-managed reserves parrotfishes tend to recover comparatively quickly and therefore increased management in protected areas and potentially fishery protection might offset the overexploitation of this species.

\section{Materials and methods}

\section{Wet lab methodologies}

\section{Sample preservation}

The fish samples were collected from Parangipettai (South east coast of India) fish landing centre in live condition and the tissue samples for DNA extraction were excised from the lateral side of Scarus rubroviolaceus and cut into small pieces $(<5-7 \mathrm{~mm})$ to permit adequate fluid penetration and preserved in fresh $95 \%$ ethanol using $1.5 \mathrm{ml}$ labeled tubes. The ethanol was poured off after few days of collection and replaced with fresh $95 \%$ ethanol to optimize DNA preservation. The tubes were stored under refrigerated condition.

\section{DNA extraction}

Salting out procedure was adapted to extract DNA from S.rubroviolaceus tissues. The preserved tissue in ethanol was washed four to five times with sterile distilled water to get clear of the ethanol content. The ethanol free tissues were transferred in to $1.5 \mathrm{ml}$ tube and grounded in micro pestle with $500 \mu \mathrm{l}$ of solution 1 (500mM Tris-HCL, 20mM EDTA and 2\% SDS).

After homogenizing the tissues were added with $5 \mu$ l of Proteinase K $(20 \mathrm{mg} / \mathrm{ml})$. The tubes were incubated at $55^{\circ} \mathrm{C}$ in water bath for 2 hours with occasional mixing by inverting the tubes. Following incubation the samples were chilled on ice for 10 minutes and about $250 \mu 1$ of solution $2(6 \mathrm{M} \mathrm{NaCl})$ was added to it and mixed well by inverting the tubes several times. Tubes were then chilled on ice for 5 minutes. Then the tubes were centrifuged at $8000 \mathrm{rpm}$ for 15 minutes and following centrifugation, $500 \mu \mathrm{l}$ of clear supernatant was collected in a $1.5 \mathrm{ml}$ tube. 
Equal volume of $(1 \mathrm{ml})$ of $100 \%$ analytical grade ethanol was added to precipitate the DNA. A thin hair like precipitate was observed after addition of ethanol. After 30 minutes the tubes were allowed to spin at $11,000 \mathrm{rpm}$ for 5 minutes. The supernatant was removed and partially dried in room temperature. The DNA pellets were washed thrice with $70 \%$ cold ethanol. The pellets were suspended in $100 \mu \mathrm{l}$ of sterile distilled $\mathrm{H}_{2} \mathrm{O}$.

\section{Quantitation of DNA by Spectrophotometric method}

- $\quad 10 \mu \mathrm{l}$ of DNA solution was diluted with $990 \mu \mathrm{l}$ of TE.

- $\quad$ Mixed well and absorbance at 260nm and 280nm was measured.

The absorbance at $260 \mathrm{~nm}$ can be used to calculate the concentration of DNA as follows:

\section{Calculations}

$\mathrm{OD}_{260}$ of $1=50 \mu \mathrm{g} / \mathrm{ml} \mathrm{DNA}$

7Dilution factor $=100$

Concentration of DNA in a given solution $=$

$\underline{50 \times \mathrm{OD} \times \text { Dilution factor } \mu \mathrm{g} / \mu \mathrm{l}}$

$1 \times 1000$

\section{PCR amplification}

\section{Primers}

The primer set MAB Fw and MAB Rw designed in the conserved region was used for the amplification of the COI region of the test organisms and the primer sequences are;

MAB Fw3: 5'-_TGTAAAACGACGGCCAGTCAACCAACCACAAAGACATTGGCAC -3’

MAB Rw3: 5'- CAGGAAACAGCTATGACACTTCAGGGTGACCGAAGAATCAGAA -3'

\section{PCR Set up}

A $1.0 \mu 1$ of Sample DNA (approximately $100 \mathrm{ng} / \mu \mathrm{l}$ ) was added to PCR Mixture containing $100 \mathrm{mM}$ Tris $\mathrm{HCl}(\mathrm{pH} 8.3), 500 \mathrm{mM} \mathrm{KCl}(\mathrm{pH} 8.3), 2.5 \mu 1 \mathrm{MgCl}_{2}(25 \mathrm{mM}), 2.0 \mu 1$ dNTP's $(2.5 \mathrm{mM}), 1.0 \mu 1$ Primer Forward \& Reverse (each of $10 \mathrm{pm} / \mu \mathrm{l}$ ) and $1 \mathrm{u} / \mu \mathrm{l}$ of Taq Polymerase (Bioserve Make) \& the final volume made to $25 \mu \mathrm{l}$ with nuclease free water.

\section{DNA sequencing}

QIAGEN QIAquick ${ }^{\mathrm{TM}}$ kit was used for sequencing reaction. The sequencing PCR was done to amplify one strand of barcode gene employing the primer FISH F1only under standard PCR conditions. The samples were precipitated and suspended in $40 \mu \mathrm{l}$ of loading solution provided with the kit. Sequencing was done with MegaBace sequencer- Bioserve India, Hyderabad.

\section{Dry lab methodologies}

\section{BOLD's identification engine}

BOLD (Barcoding of life database) is an online workbench that aids in collection, management, analysis, and use of DNA barcodes. Identification engine is the one of the important components of BOLD database which consists of large volume of barcode sequences for both plants (intranuclear spacer gene) and animals (cytochrome c oxidase subunit gene). BOLD-IDS provide a species identification tool 
that accepts DNA sequences from the barcode region and returns a taxonomic assignment to the species level when possible. The BOLD identification system (IDS) accepts sequences from the 5' region of the mitochondrial gene cytochrome oxidase subunit I and returns species-level identification when one is possible. Further validation with independent genetic markers will be desirable in some forensic applications. This identification engine was accessible online through http://www.barcodinglife.org/views/ idrequest. php. The sequences were given in FASTA file format in the query box and results were obtained similar to that of BLAST search.

\section{Profiling the barcode region of Scarus rubroviolaceus}

The molecular weight of the single stranded barcode DNA was calculated as the sum of the monophosphate forms of each deoxyribonucleotide minus one water molecule each. One water (18 Da) was added at the end to represent the 3' hydroxyl at the end of the chain and one more hydrogen atom at the 5' phosphate end. Nucleotide composition summaries and plots were obtained by choosing "Nucleotide Composition" form the "Nucleic Acid" submenu of the "Sequence" menu. Bar plots showed the Molar percent of each residue in the sequence. The degenerate nucleotide designations were added to the plot wherever they are encountered. Any DNA sequence has only A, G, C and T and these were represented by four bars on the graph.

\section{Barcode protein profiling}

\section{DNA to Protein}

The online software at www.insilico.ehu.es was used to extract hypothesized amino acid sequences from the COI region of Scarus rubroviolaceus. This software allowed modeling and modifications of already existing techniques, as well as new theoretical approaches. Standard genetic code translation was used. DNA sequences were fed in to the query box in FASTA format. Minimum size of protein sequence for Open Reading Frames (ORF) is customizable and they were trimmed to MET-to-Stop.MShowing translation alignment was optional, and aminoacids were displaied as a 1-letter aminoacids code.

\section{1-letter aminoacid codes}
A alanine
$\mathrm{P}$ proline
B aspartate or asparagine
Q glutamine
C cysteine
D aspartate
$\mathrm{R}$ arginine
E glutamate
$\mathrm{S}$ serine
$F$ phenylalanine
$\mathrm{T}$ threonine
$\mathrm{G}$ glycine
$\mathrm{U}$ selenocysteine
$\mathrm{H}$ histidine
$\mathrm{V}$ valine
I isoleucine
W tryptophan
$\mathrm{K}$ lysine
Y tyrosine
L leucine
$\mathrm{Z}$ glutamate or glutamine
M methionine
$\mathrm{X}$ any
$\mathrm{N}$ asparagine

Amino acid composition summaries and plots were obtained by choosing "Amino Acid Composition" from the "Protein" submenu of the "Sequence" menu. Bar plots showed the Molar percent of each residue in the sequence (Fig 10). Amino Acid plots and summaries were similar, though residues other than the standard 20 amino acids were ignored. A helical wheel is a type of plot or visual representation used to illustrate the properties of alpha helices in proteins. The sequence of amino acids 
that make up a helical region of the protein's secondary structure are plotted in a rotating manner where the angle of rotation between consecutive amino acids is $100^{\circ}$, so that the final representation looks down the helical axis. The plot reveals whether hydrophobic amino acids are concentrated on one side of the helix, usually with polar or hydrophilic amino acids on the other (Fig 11).

\section{CLUSTAL W}

Clustal W is a general purpose global multiple sequence alignment program for DNA or proteins. It produces biologically meaningful multiple sequence alignments of divergent sequences. It calculates the best match for the selected sequences, and lines them up so that the identities, similarities and differences can be seen. Evolutionary relationships can be seen via viewing Cladograms or Phylograms.

\section{Phylogenetic tree construction using MEGA}

Neighborhood joining (NJ) method of phylogenetic tree construction was preferred for accurate establishment of phylogenetic relationship and to trace out the presence of phylogenetic signals in the DNA sequences $^{32}$. The distance was calculated between every pair of sequences and these were used to construct the phylogenetic tree which guided the final multiple alignment. The scores were calculated from separate pair wise alignments.

\section{MEGA (Molecular Evolutionary Genetic Analysis) version 5}

MEGA is an integrated tool for conducting automatic and manual sequence alignment, inferring phylogenetic trees, mining the web base data bases, estimating the rates of molecular evolution, and testing evolutionary hypothesis ${ }^{34}$.

\section{Bootstrapping}

One of the most commonly used tests of the reliability of an inferred tree is ${ }^{35}$ bootstrap test which is evaluated using ${ }^{36}$ bootstrap resampling technique. If there are $m$ sequences, each with $n$ nucleotides (or codons or amino acids) a phylogenetic tree can be reconstructed using the same tree building method. From each sequence $n$ nucleotides were randomly chosen with replacements, giving rise to $m$ rows of $n$ columns each. These now constitute a new set of sequences.

A tree is then reconstructed with these new sequences using the same tree building method as before. Next the topology of this tree was compared to that of the original tree. Each interior branch of the original tree that was different from the bootstrap tree the sequence it partitions is given a score of 0 all other interior branches was given the value 1 was noted. This procedure of re-sampling the sites and the subsequent tree reconstruction was repeated several hundred times and the percentage of times each interior branch was given a value of 1 was noted. This is known as the bootstrap value.

The multiple aligned sequences from Clustal $\mathrm{X}$ were loaded into MEGA through Create New Alignment option in Alignment menu. The sequences were trimmed for their conserved regions and saved in MEGA format for phylogram construction. Bootstrap test for phylogeny was preferred to detect the reliability of each branch in phylogram. As a general rule if the bootstrap value for a given interior branch is $95 \%$ or higher than the topology of that branch then the value is considered "correct" 12 .

\section{Results}

\section{Quantitation of DNA by electrophoresis}

A thick band was seen above the $300 \mathrm{~kb}$ band of $\lambda$ Hind III marker (marker not shown here). This indicates high molecular nature of genomic DNA (Fig1). In the electropherogram the bands of the size 
700bp (for sample MAB06) was observed against 100bp DNA ladder (Fig 2). There was no overlapping of the bands in the case of test organisms and that way the bands were clear.

\section{Top 10 Sequences Producing Significant Alignments from NCBI}

The sequences were checked for considerable alignments from NCBI. About 10 sequences showed significant alignments of which the maximum identity ranged from $99 \%$ to $94 \%$. The maximum score ranged from 1153 to 991 . The query coverage was found to be as $100 \%$. The summary of the results is depicted in Fig 3. The distance tree comparison of the study organism showed similar evolutionary similarity with Scarus rubroviolaceus (Fig 4).

\section{BOLD's search}

Identification summary (Fig 5) showed the probability of placement (99.8\%) along with taxonomic level and taxon assignment. The distance summary is illustrated in Fig 6. A species level match has been made. The bolds search showed top 20 specimen similarity with $96.11 \%$ to $99.84 \%$. (Fig 7). The COI species database tree confirmed that the study organism belongs to the order Perciformes which was very closely related with Scarus rubroviolaceus (Fig. 8).

\section{Accession numbers of sequences closely related to the Test organism used in the analysis \& their locations.}

The test organisms were reviewed for close relations to the test organism (JX120608) for which the accession numbers were cross checked from the database. The accession numbers were EF609452 (Australia) FJ584082 (Tonga), GU805008 (South Africa), HQ149928 (Iran).

\section{Profiling the barcode region of Scarus rubroviolaceus}

Nucleotide composition summaries were obtained and shown in Table 1. The table represents the Molar concentration of DNA nucleotides in the COI region of Scarus rubroviolaceus sample (MAB06) from Parangipettai waters versus closely related organisms. Upon comparison the results showed that the thymine and cytosin content was high and While comparing with all the samples they are different . The least molar concentration was observed in guanine in all the samples.

\section{Barcode protein profiling}

\section{DNA to Protein}

The protein's secondary structures of figure 11 explains the alpha helices in proteins showing that hydrophobic aminoacids of Alanine (A), Isoleucine (I), Leucine (L), Phenylalanine (F), Valine (V), Glycine $(\mathrm{G})$ where concentrated as groups, and only Serine $(\mathrm{S})$, Threonine $(\mathrm{T})$ and Tyrosine $(\mathrm{Y})$ interfered between those hydrophobic aminoacids in the first circle.

\section{CLUSTAL W}

The similarities between two or more DNA sequences were compared using multiple sequence alignments. The query sequences were posted on the query box in Clustal W from the tools option of EMBL. The results page displays the similarities between the sequences. The similarities in sequences of the study animal with intra species is shown in fig 9.

\section{Evolutionary relationships of taxa by UPGMA Method}

From fig 12 we are resulted that the evolutionary history was inferred using the UPGMA method. The optimal tree with the sum of branch length $=8.67922062$ is shown. The tree is drawn to scale, with branch lengths in the same units as those of the evolutionary distances used to infer the phylogenetic tree. 
The evolutionary distances were computed using the Maximum Composite Likelihood method and are in the units of the number of base substitutions per site. The analysis involved 5 nucleotide sequences. Codon positions included were $1 \mathrm{st}+2 \mathrm{nd}+3 \mathrm{rd}+$ Noncoding. All positions containing gaps and missing data were eliminated. There were a total of 642 positions in the final dataset. Evolutionary analyses were conducted in MEGA5.

\section{Discussion}

This study clearly revealed that COI (mitochondrial cytochrome c oxidase subunit I) could be a barcode sequence distinguishing Scarus rubroviolaceus to its species level both through the phylogram and by search result of barcode of life database in fig 5. Minimum evolutionary distance of 0.02 in the scale was observed (Fig 12). While comparing the Phylogeographical signals and the arrangement of Scarus rubroviolaceus (MAB06) sample from parangipettai with Australia (EF609452), Tonga (FJ584082), South Africa (GU805008), Iran (HQ149928). The parangipettai sample is closely relationship with Iran sample with same distance of about 0.0210 (Fig 12)which may indicates that the species have evolved from Bushehr, Iran "27.40 N 52.60 E" to India ("11 $29^{\prime}$ N, Long $\left.79^{0} 46^{\prime} \mathrm{E}^{\prime}\right)$ or vise versa. Surprisingly here the result also denotes that Australian ("11.62 S 143.57 E") species (EF609452) and South African ("30.333 S 30.75 E") species have same evolution relationship of 0.0201(Fig 12) as the distance between the two region is too long. The Tonga species (FJ584082) was the most isolated and genetically diversed while comparing to those other four samples of about 0.0322 (Fig 12) as may due to the enterly different region in the world map and notably worlds most divergent species living biggest island Australia is also distanced to this Tonga region.

It was observed that other one Scarus rubroviolaceus from Iran Sea shows $99.84 \%$ by which it conforms the species Scarus rubroviolaceus.. The profiling study on the barcode regions of Scarus rubroviolaceus revealed that barcode region was rich in thaimin and cytosine consisting equal value of about $29.3 \%$ and $18.5 \%$ as least of guanine content. The GC content of Scarus rubroviolaceus from various waters was found to be about $47.8 \%$. The protein's secondary structures of figure 11 exposing hydrophobic aminoacids concentrated as groups which reveals that one face of the helix is oriented towards the hydrophobic core and other face is oriented towards the solvent exposed surface of the alpha helical globular proteins. This will makes the further steps for characterizing the protein folds and its docking motifs.

\section{Acknowledgements}

The authors are thankful to the supports form SERB Sanction order No. SR /FT / LS-125/2011 and University Grants Commission, Govt of India research project No: F. No: 41- 4/2012 (SR) for providing funds and authority of Annamalai Unveristy for providing facility for this work.

\section{Reference}

1. Hebert P D N, Cywinska A, Ball S L \& deWaard J R, Biological identifications through DNA barcodes. Proc. R. Soc. Lond. 270 (2003) 313-321.

2. Radulovici A E, Archambault P \& Dufresne, F. DNA Barcodes for Marine Biodiversity: Moving Fast Forward?. Diversity, 2 (2010) 450-472

3. Galtier N, Nabholz B, Glémin S \& Hurst G D D, Mitochondrial DNA as a marker of molecular diversity: a reappraisal. Mol. Ecol., 18 (2009) 4541-4550.

4. Haq M A B, Azarudeen D M, Vignesh R, Kumar T T A \& Srinivasan M, Identification and intra species delineation of ornamental silver pompano (Trachinotus blochi, Lacepede, 1801) with DNA barcodes. International Research Journal of Biochemistry and Bioinformatics.,3 (2013) 26-36. 
5. Miller S E, DNA barcoding and the renaissance of taxonomy. Proceedings of the National Academy of Sciences 104 (2007) 4775-4776.

6. Fre'zal L \& Leblois R, Four years of DNA barcoding: Current advances and prospects. Infection, Genetics and Evolution, 8 (2008) 727-736.

7. Wilson E O,. The Encyclopaedia of Life. Trends Ecol. Evol., 18 (2004) 77-80.

8. Hallden C, Nilsson N O, Rading M I \& Sall T, Evaluation of RFLP and RAPD markers in comparison of Brassica napus breeding lines. Theor. Appl. Genet., 88 (1994) 123-128.

9. Lievens S, Goormachtig S, \& Holsters M, A critical evaluation of differential display as a tool to identify genes involved in legume nodulation: looking back and looking forward. Nucleic Acids Res., 29 (2001) 3459-3468.

10. Ward R D, Zemlak T S, Innes B H, Last P R \& Hebert P D N, DNAbarcoding Australia's fish species. Phil. Trans. R. Soc., 360 (2005) 1847-1857.

11. Hubert N, Hanner R, Holm E, Mandrak N E, Taylor E et al, Identifying Canadian Freshwater Fishes through DNA Barcodes. Plos One, 3 (2008) 1-5.

12. Steinke D, Zemlak T S, Boutillier J A \& Hebert P D N, DNAbarcoding of Pacific Canada's fishes. Mar Biol., 156 (2009) 2641-2647.

13. Westneat M W \& Alfaro E M, Phylogenetic relationships and evolutionary history of the reef family Labridae. Molecular Phylogenetic and Evolution, 36 (2005);370-390

14. Smith L L, Fessler J L, Alfaro M E, Streelman J T \& Westneat M W, Phylogenetic relationships and the evolution of regulatory gene sequences in the parrotfishes. Molecular Phylogenetics and Evolution, 49 (2008) 136-152.

15. Choat J H, Myers R, Clements K D, Russell B, Rocha L A et al, 2012. Scarus rubroviolaceus, in IUCN 2012. IUCN Red List of Threatened Species. Version 2012.2.

16. Fitzpatrick J M, Carlon D B, Lippe C \& Robertso D R, The West Pacific diversity hotspot as a source or sink for new species? Population genetic insights from the Indo-Pacific parrotfish Scarus rubroviolaceus. Molecular Ecology, 20 (2011) 219-234.

17. Winters K L L, Choat H J H \& Robertson D R, Phylogeography of the Indo-Pacific parrotfish Scarus psittacus: isolation generates distinctive peripheral populations in two oceans. Marine Biology, 157 (2010) 1679-1691

18. Connell S D, Samoilys M A, Smith M P L \& Leqata, J, Comparison of abundance of coral-reef fish: catch and effort surveys vs. visual census. Austral Ecology, 23 (1998) 579-586.

19. Jennings S, Reynolds J D \& Polunin N V C, Predicting the vulnerability of tropical reef fishes to exploitation with phylogenies and life histories. Conservation Biology, 13 (1999) 1466-1475

20. McClanahan T R, Muthiga N A, Kamukuru A T, Machano H \& Kiambo R W, The effects of marine parks and fishing on coral reefs of northern Tanzania. Biological Conservation, 89 (1999) 161-182

21. Grandcourt E M, Demographic characteristics of a selection of exploited reef fish from the Seychelles: preliminary study. Marine and Freshwater Research, 53 (2002) 123-130. 
22. Ong L, The ecological importance of parrotfish as bioeroders and sediment producers and their conservation within small marine protected areas. (ProQuest, University of Hawaii, Manoa) 2007, 1133.

23. Price S A, Wainwright P C, Bellwood D R, Kazancioglu E, Collar D C et al, Functional innovations and morphological diversification in parrotfish. Evolution, 64 (2010) 3057-3068.

24. Done T J, Phase-shifts in coral reef communities and their ecological significance. Hydrobiologia, 247 (1992) 121-132.

25. Williams I D, Polunin N V C \& Hendrick V J, Limits to grazing by herbivorous fishes and the impact of low coral cover on macroalgal abundance on a coral reef in Belize. Mar Ecol Prog Ser., 222 (2001) 187-196

26. Mumby P J, The impact of exploiting grazers (Scaridae) on the dynamics of Caribbean coral reefs. Ecol Appl., 16 (2006) 747-769

27. Smith M K,. An ecological perspective on inshore fisheries in main Hawaiian islands: (Fisheries of Hawaii and US associated Pacific Islands). Mar Fish Rev., 55 (1993) 34-49.

28. Anonynous, Biology of parrotfish in Hawaii, A report prepared for the western pacific regional fishery managemant council, Final report 2008 (Hawaii corporation fishery research unit. Univeraity of Hawaii at Manoa Campus), 1-38.

29. Poepoe K K, Bartram P \& Friedlander A, The use of traditional Hawaiian knowledge is the contemporary management of marine resources. In: Putting fishers' Knowledge to work, Fisheries Center Research Report, Universit of British Colombia. Vancouver. 11 (2003) 328-339.

30. Thresher R E, Reproduction in reeffishes. (Tfh Publications, Neptune City, New Jersey) 1984, 1-299.

31. Kathrine H G, Community structure, life history, and movement patterns of parrotfishes: large protogynous fishery species. Ph. D Thesis. University of Hawaii, Hawaii, 2008

32. Nei M \& Kumar S, Molecular evolution and Phylogenetics (Oxford University press, New York) 2000, 1-333.

33. Tamura K, Dudley J, Nei M \& Kumar S, Molecular Evolutionary Genetics Analysis (MEGA) software version 4.0. Mol Bio Evol. 24 (2007) 1596-1599.

34. Felsenstein J, Confidence limits on phylogenies: An approach using the bootstrap. Evolution. 39 (1985) 783-791.

35. Efron's B,. The Jackknife, the bootstrap and other resampling plans (Society for Industrial and Applied Mathematics, SIAM, Philadelphia) 1982, 29-36. 


\section{FIGURES AND TABLES}

Table 1 Nucleotide composition of Test organism \& closely related sequences

\begin{tabular}{|c|c|c|c|c|c|c|c|c|}
\hline \multirow{2}{*}{$\begin{array}{c}\text { Name of } \\
\text { species }\end{array}$} & \multirow[t]{2}{*}{ Accession ID } & \multirow{2}{*}{$\begin{array}{c}\text { Base pair } \\
\text { length }\end{array}$} & \multirow{2}{*}{$\begin{array}{c}\mathbf{G}+\mathbf{C} \\
\text { content } \\
(\%)\end{array}$} & \multirow{2}{*}{$\begin{array}{c}\mathbf{A}+\mathbf{T} \\
\text { content } \\
(\%)\end{array}$} & \multicolumn{4}{|c|}{$\begin{array}{c}\text { Nucleotide Number and } \\
\text { Mol\% }\end{array}$} \\
\hline & & & & & A & $\mathrm{T}$ & $\mathrm{G}$ & $\mathrm{C}$ \\
\hline \multirow[t]{10}{*}{ МАВ06 } & JX120608 & 642 & $47.8 \%$ & $52.2 \%$ & 147 & 188 & 119 & 188 \\
\hline & & & & & $22.9 \%$ & $29.3 \%$ & $18.5 \%$ & $29.3 \%$ \\
\hline & EF609452 & 655 & $48.5 \%$ & $51.5 \%$ & 149 & 188 & 120 & 198 \\
\hline & & & & & $22.7 \%$ & $28.7 \%$ & $18.3 \%$ & $30.2 \%$ \\
\hline & FJ584082 & 652 & $47.4 \%$ & $52.6 \%$ & 153 & 190 & 117 & 192 \\
\hline & & & & & $23.5 \%$ & $29.1 \%$ & $17.9 \%$ & $29.4 \%$ \\
\hline & GU805008 & 652 & $48.0 \%$ & $52.0 \%$ & 149 & 190 & 119 & 194 \\
\hline & & & & & $22.9 \%$ & $29.1 \%$ & $18.3 \%$ & $29.8 \%$ \\
\hline & HQ149928 & 648 & $48.6 \%$ & $51.4 \%$ & 148 & 185 & 121 & 194 \\
\hline & & & & & $22.8 \%$ & $28.5 \%$ & $18.7 \%$ & $29.9 \%$ \\
\hline
\end{tabular}


Figure 1 Genomic DNA (sample MAB02) were shown 300kb band

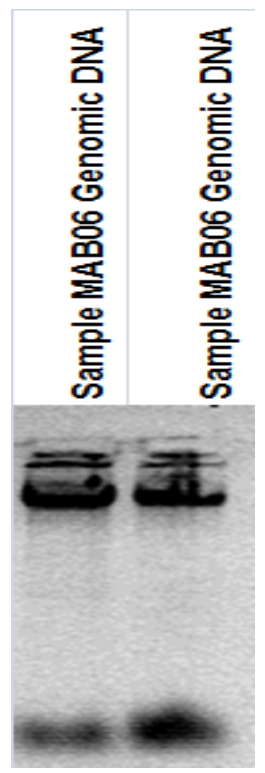

Figure 2 Electrophoresing the amplicons size were shown $\sim 700 \mathrm{bp}$.

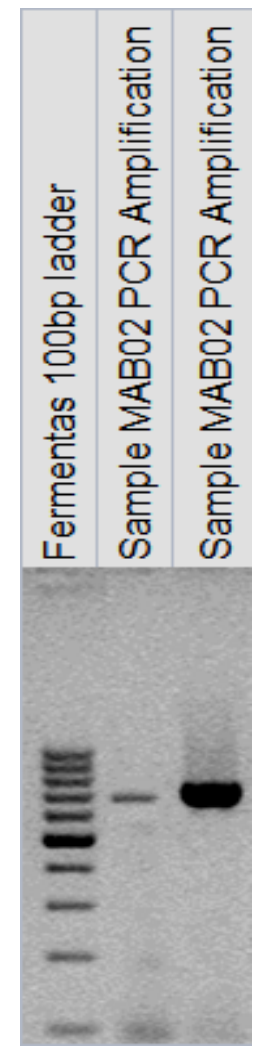


Figure 3 Top 10 Sequences Producing Significant Alignments from NCBI

Sequences producing significant alignments:

\begin{tabular}{|c|c|c|c|c|c|c|}
\hline Accession & Description & Max score & $\underline{\text { Total score }}$ & Query coverage & $\triangle \underline{E \text { value }}$ & Max ident \\
\hline$\underline{\text { GU805008.1 }}$ & Scarus rubroviolaceus voucher ADC09_221.15\#7 cytochrome oxidase & $\underline{1153}$ & 1153 & $100 \%$ & 0.0 & $99 \%$ \\
\hline$\underline{F] 227899.1}$ & Scarus rubroviolaceus mitochondrion, complete genome & $\underline{1122}$ & 1122 & $100 \%$ & 0.0 & $99 \%$ \\
\hline$\underline{\mathrm{HQ149928.1}}$ & Scarus ghobban voucher NPPF1123 cytochrome oxidase subunit 1 (C & $\underline{1041}$ & 1041 & $100 \%$ & 0.0 & $96 \%$ \\
\hline$\underline{E F 609452.1}$ & Scarus ghobban voucher BW-A1264 cytochrome oxidase subunit 1 (। & $\underline{1041}$ & 1041 & $100 \%$ & 0.0 & $96 \%$ \\
\hline F]449707.1 & Scarus ghobban mitochondrion, complete genome & $\underline{1036}$ & 1036 & $100 \%$ & 0.0 & $96 \%$ \\
\hline$\underline{\mathrm{HQ149930.1}}$ & Scarus ghobban voucher NPPF1097 cytochrome oxidase subunit 1 (C & $\underline{1032}$ & 1032 & $100 \%$ & 0.0 & $96 \%$ \\
\hline$\underline{F] 237699.1}$ & Chlorurus gibbus voucher MBCSC:HN SY08421 cytochrome oxidase s। & $\underline{1023}$ & 1023 & $98 \%$ & 0.0 & $96 \%$ \\
\hline$\underline{F] 584082.1}$ & Scarus iseri voucher HLC-12101 cytochrome oxidase subunit 1 (COI) & $\underline{996}$ & 996 & $100 \%$ & 0.0 & $94 \%$ \\
\hline$\underline{\text { GU225430.1 }}$ & Scarus iseri voucher MX103 cytochrome oxidase subunit 1 (COI) gen & $\underline{991}$ & 991 & $100 \%$ & 0.0 & $94 \%$ \\
\hline$\underline{\text { GU225429.1 }}$ & Scarus iseri voucher MX104 cytochrome oxidase subunit 1 (COI) gen & $\underline{991}$ & 991 & $100 \%$ & 0.0 & $94 \%$ \\
\hline
\end{tabular}

\section{Figure 4 The Distance Tree of the Results from NCBI}

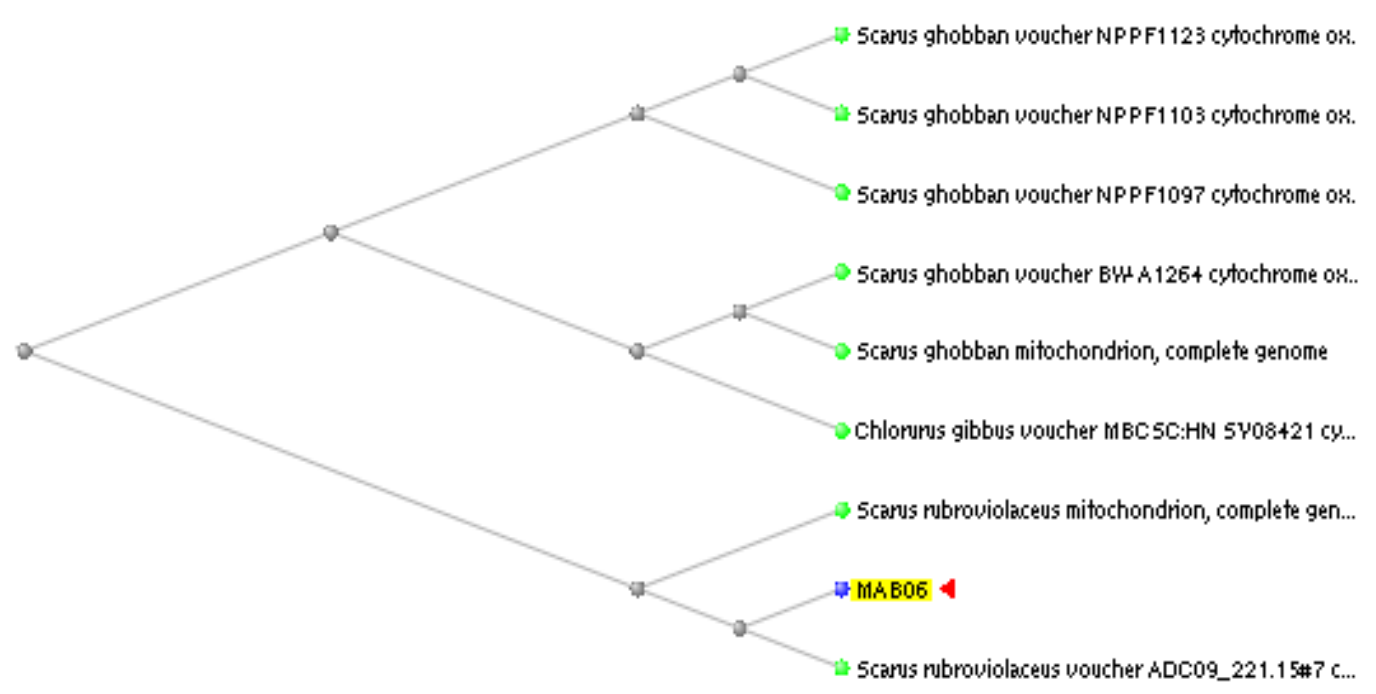




\section{Figure 5 BOLD's search Result}

Search Request:

Type :

COI SPECIES DATABASE

Search Result:

Identification Summary :

\begin{tabular}{|ccc|}
\hline Taxonomic Level & $\begin{array}{c}\text { Taxon } \\
\text { Assignment }\end{array}$ & $\begin{array}{c}\text { Probability of } \\
\text { Placement (\%) }\end{array}$ \\
\hline phylum & Chordata & 100 \\
class & Actinopterygii & 100 \\
order & Perciformes & 100 \\
family & Scaridae & 100 \\
genus & Scarus & 100 \\
species & Scarus & 99.8 \\
\hline
\end{tabular}

A species level match has been made. This identification is solid unless there is a very closely allied congeneric species that has not yet been analyzed. Such cases are rare.

Figure 6 Result of the distance summary

Distance Summary :

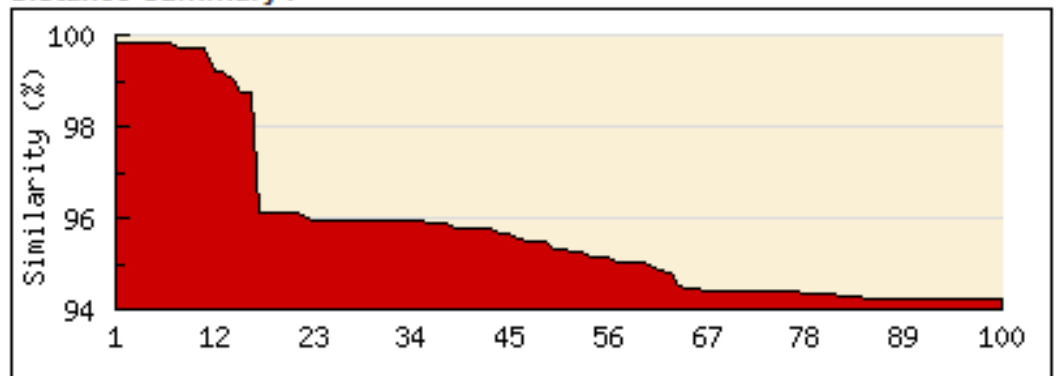

Similarity scores of the top 100 matches 
Figure 7 Results of top 20 specimen similarity with $99.68 \%$ to $100 \%$.

\begin{tabular}{|c|c|c|c|c|c|c|}
\hline Phylum & Class & Order & Family & Genus & Species & $\begin{array}{c}\text { Specimen } \\
\text { Similarity }(\%)\end{array}$ \\
\hline Chordata & Actinopterygii & Perciformes & Scaridae & Scarus & rubroviolaceus & 99.84 \\
\hline Chordata & Actinopterygii & Perciformes & Scaridae & Scarus & rubroviolaceus & 99.84 \\
\hline Chordata & Actinopterygii & Perciformes & Scaridae & Scarus & rubroviolaceus & 99.84 \\
\hline Chordata & Actinopterygii & Perciformes & Scaridae & Scarus & rubroviolaceus & 99.84 \\
\hline Chordata & Actinopterygii & Perciformes & Scaridae & Scarus & rubroviolaceus & 99.84 \\
\hline Chordata & Actinopterygii & Perciformes & Scaridae & Scarus & rubroviolaceus & 99.84 \\
\hline Chordata & Actinopterygii & Perciformes & Scaridae & Scarus & rubroviolaceus & 99.84 \\
\hline Chordata & Actinopterygii & Perciformes & Scaridae & Scarus & rubroviolaceus & 99.69 \\
\hline Chordata & Actinopterygii & Perciformes & Scaridae & Scarus & rubroviolaceus & 99.69 \\
\hline Chordata & Actinopterygii & Perciformes & Scaridae & Scarus & rubroviolaceus & 99.69 \\
\hline Chordata & Actinopterygii & Perciformes & Scaridae & Scarus & rubroviolaceus & 99.69 \\
\hline Chordata & Actinopterygii & Perciformes & Scaridae & Scarus & rubroviolaceus & 99.22 \\
\hline Chordata & Actinopterygii & Perciformes & Scaridae & Scarus & rubroviolaceus & 99.22 \\
\hline Chordata & Actinopterygii & Perciformes & Scaridae & Scarus & rubroviolaceus & 99.05 \\
\hline Chordata & Actinopterygii & Perciformes & Scaridae & Scarus & rubroviolaceus & 98.75 \\
\hline Chordata & Actinopterygii & Perciformes & Scaridae & Scarus & rubroviolaceus & 98.75 \\
\hline Chordata & Actinopterygii & Perciformes & Scaridae & Scarus & ghobban & 96.11 \\
\hline Chordata & Actinopterygii & Perciformes & Scaridae & Scarus & ghobban & 96.11 \\
\hline Chordata & Actinopterygii & Perciformes & Scaridae & Scarus & ghobban & 96.11 \\
\hline Chordata & Actinopterygii & Perciformes & Scaridae & Chlorurus & gibbus & 96.11 \\
\hline
\end{tabular}

\section{Figure 8 COI SPECIES DATABASE Tree}

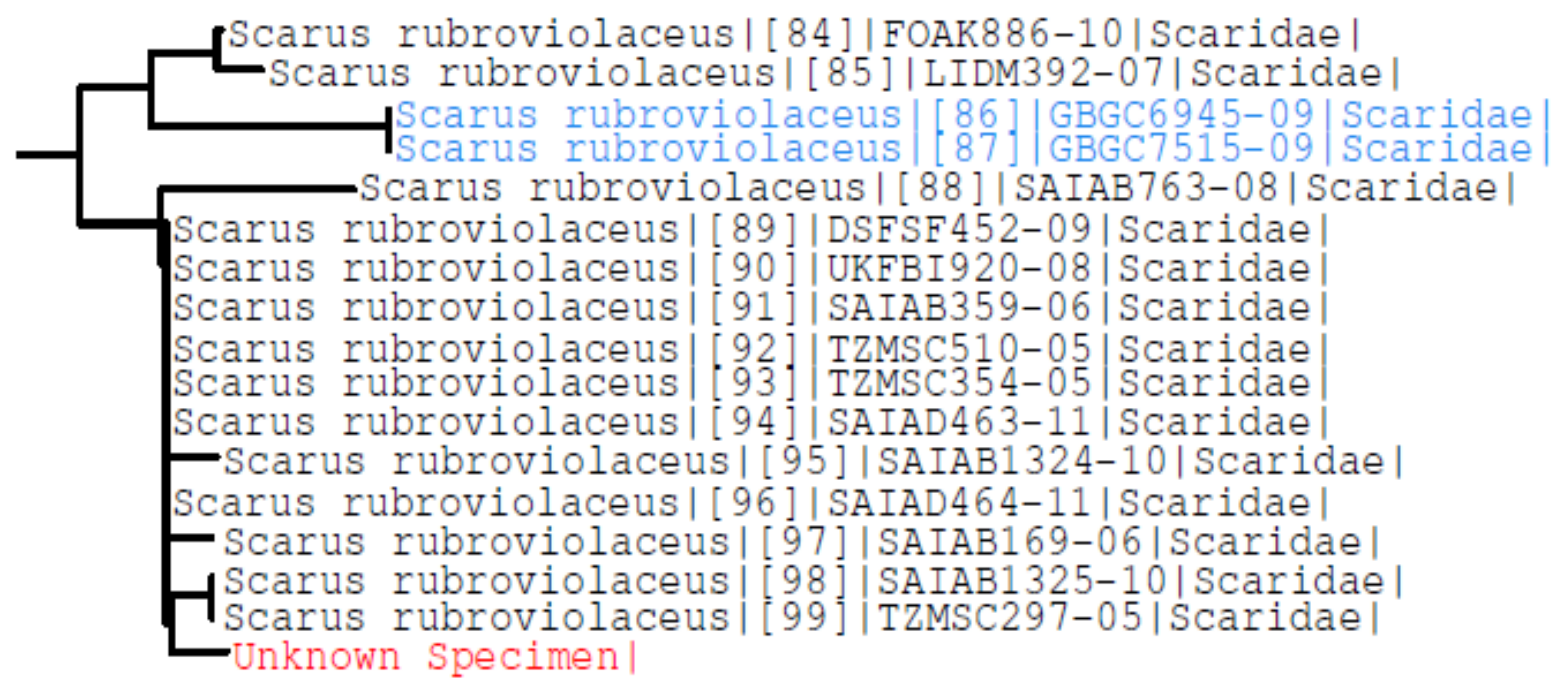


IRA-International Journal of Applied Sciences

Figure 9 CLUSTAL 2.0.10 Multiple Sequence Alignments

MAB06 EF609452 FJ584082 GU805008 HQ149928

MABO6 EF609452 FJ584082 GU805008 HQ149928

MABO 6 EF609452 FJ584082 GU805008 HQ149928

MABO6 EF609452 FJ584082 GU805008 HQ149928

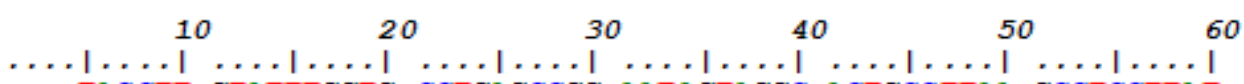
TACCTT GTATTTGGTG CCTGAGCCGG AATAGTAGGC ACTGCCTTAA GCCTCCTTAT CCTTTACCTT GTATTTGGTG CCTGAGCCGG AATAGTAGGC ACTGCCTTAA GCCTCCTCAT CCTTTACCTT GTATTTGGTG CCTGAGCCGG AATAGTAGGC ACTGCCTTAA GCCTCCTCAT CCTTTACCTT GTATTTGGTG CCTGAGCCGG AATAGTAGGC ACTGCCTTAA GCCTCCTTAT --TACCTT GTATTTGGTG CCTGAGCCGG AATAGTAGGC ACTGCCTTAA GCCTCCTTAT

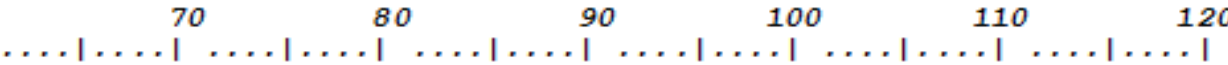
CCGAGCTGAA CTAAGTCAAC CCGGGGCCCT TCTCGGAGAC GACCAGATTT ATAATGTAAT CCGAGCTGAA CTAAGTCAAC CCGGGGCCCT TCTCGGAGAC GACCAGATTT ATAATGTTAT CCGAGCTGAA TTAAGTCAAC CCGGGGCCCT TCTCGGAGAC GACCAGATTT ATAATGTTAT CCGAGCTGAA CTAAGTCAAC CCGGGGCCCT TCTCGGAGAC GACCAGATTT ATAATGTAAT CCGAGCTGAA CTAAGTCAAC CCGGGGCCCT TCTCGGAGAC GACCAGATTT ATAATGTTAT

$$
\begin{array}{cccccc}
130 & 140 & 150 & 160 & 170 & 180
\end{array}
$$

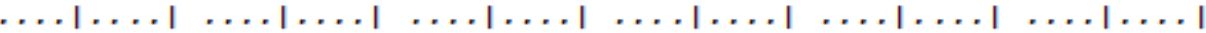

117 CGTTACAGCT CATGCATTTG TAATGATCTT TTTTATAGTC ATGCCTATCA TGATTGGAGG 121 CGTTACAGCT CATGCATTTG TAATGATCTT TTTTATAGTC ATGCCTATCA TGATTGGAGG 121 CGTTACAGCT CATGCATTTG TAATAATCTT TTTTATAGTC ATGCCTATCA TGATTGGAGG 121 CGTTACAGCT CATGCATTTG TAATGATCTT TTTTATAGTC ATGCCTATCA TGATTGGAGG 117 CGTTACAGCT CATGCATTTG TAATGATCTT TTTTATAGTT ATGCCTATCA TGATTGGAGG

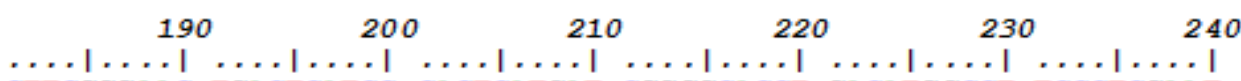
177 CTTCGGGAAC TGACTCATCC CACTCATGAT CGGGGCACCT GACATGGCCT TCCCTCGAAT 181 CTTCGGGAAC TGACTCATCC CACTCATGAT TGGAGCACCT GACATAGCCT TCCCTCGAAT 181 CTTCGGAAAC TGACTCATCC CGCTCATGAT CGGAGCACCC GACATGGCCT TCCCTCGAAT 181 CTTCGGGAAC TGACTCATCC CACTCATGAT CGGGGCACCT GACATGGCCT TCCCTCGAAT 177 CTTCGGGAAC TGACTCATCC CACTCATGAT TGGAGCACCT GACATGGCCT TCCCTCGAAT
MABO6

EF609452 FJ584082 GU805008 HQ149928

MABO6

EF609452 FJ584082 GU805008 HQ149928

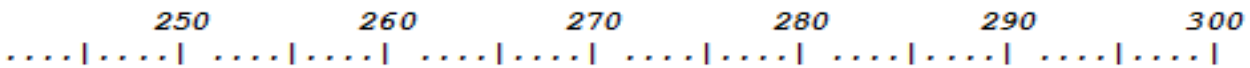
237 GAACAATATG AGCTTCTGAC TTCTCCCTCC TTCCTTTCTT CTATTGCTCG ССTCCTCTGG 241 GAACAATATG AGCTTCTGAC TCCTTCCTCC TTCCTTCCTC CTATTGCTCG CCTCCTCTGG 241 GAACAATATG AGCTTCTGAC TTCTCCCTCC СTCСTTTCTC СTATTACTCG ССTCCTCTGG 241 GAACAATATG AGCTTCTGAC TTCTCCСTCC TTCСTTTCTT СTATTGCTCG ССТССTCTGG 237 GAACAATATG AGCTTCTGAC TCCTTCCTCC CTCCTTCCTC СTATTGCTCG CСTCCTCTGG

$\begin{array}{rrrrr}310 & 320 & 330 & 340 & 350\end{array}$

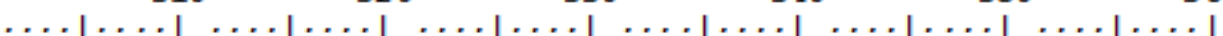
297 CGTAGAAGCA GGAGCAGGTA CCGGATGGAC CGTTTACCCC CCTCTAGCAG GGAATCTTGC 301 CGTAGAAGCA GGAGCAGGTA CCGGATGGAC CGTTTACCCC CCTCTAGCAG GGAATCTTGC 301 CGTAGAAGCA GGAGCAGGTA CCGGATGAAC CGTTTACCCC CCTCTAGCAG GAAATCTTGC 301 CGTAGAAGCA GGAGCAGGTA CCGGATGGAC CGTTTACCCC CCTCTAGCAG GGAATCTTGC 297 CGTAGAAGCA GGGGCAGGTA CCGGATGGAC CGTTTACCCC CCTCTAGCAG GGAATCTTGC

$$
\begin{aligned}
& \begin{array}{llllll}
370 & 380 & 390 & 400 & 410 & 420
\end{array}
\end{aligned}
$$

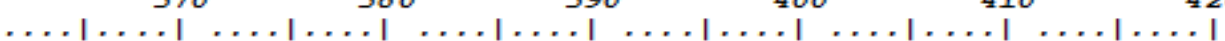

MABO6 EF609452 FJ584082 GU805008 $\underline{\text { HQ149928 }}$

MABO6 EF609452 FJ584082 GU805008 HQ149928 357 ACACGCAGGT GCATCCGTTG ACCTAACAAT CTTCTCCCTT CACCTAGCAG GAATTTCGTC 361 ACACGCAGGG GCATCCGTTG ACCTAACAAT TTTCTCTCTT CACCTAGCAG GGATTTCATC 361 ACACGCAGGT GCATCCGTTG ATCTGACAAT CTTTTCCCTT CACCTAGCAG GAATTTCTTC 361 ACACGCAGGT GCATCCGTTG ACCTAACAAT CTTCTCCCTT CACCTAGCAG GAATTTCGTC 357 ACACGCGGGA. GCATCCGTTG ACCTAACAAT TTTCTCTCTC CACCTAGCAG GGATTTCATC

$\begin{array}{rrrrrr}430 & 440 & 450 & 460 & 470 & 480\end{array}$

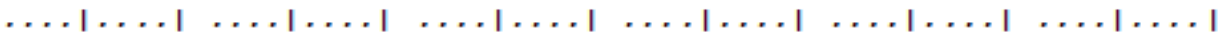
417 TATTCTAGGC GCAATTAACT TTATTACAAC CATCATTAAC ATAAAACCGC CTGCCATCTC 421 TATTCTAGGC GCAATCAACT TTATCACAAC CATCATTAAC ATGAAACCGC CTGCCATCTC 421 TATCCTAGGG GCAATTAACT TCATTACAAC AATTATTAAC ATAAAACCAC CTGCCATCTC 421 TATTCTAGGC GCAATTAACT TTATTACAAC CATCATTAAC ATAAAACCGC CTGCCATCTC 417 TATTCTAGGC GCAATCAACT TTATTACAAC CATCATTAAC ATAAAACCGC CTGCCATCTC 


\begin{tabular}{|c|c|c|c|c|c|c|}
\hline & & 490 & 510 & 52 & 530 & 540 \\
\hline & 477 & CCA $|\ldots \ldots|$ I $\ldots|\ldots| \ldots \mid$ & TCGTATGAGC & $\begin{array}{l}\ldots \text {. } \\
\text { TGT CTTAATT }\end{array}$ & $\mid \begin{array}{l}\text { C. } \\
\text { CCTCC }\end{array}$ & \\
\hline 9452 & 481 & TACCAA ACGCCCCTAT & TCGTATGAGC & TGT TTTAATT & ACTGCCGTGC & TTCTTCTCCT \\
\hline$\overline{F J 584082}$ & 481 & CCAGTACCAA АCCCCACTGT & TCGTATGGGC & TGTTTTAATT & ACTGCCGTAC & ТССТТСТССТ \\
\hline$\overline{\text { GU805008 }}$ & 481 & CCAGTACCAA ACACCCCTCT & TCGTATGAGC & TGT CTTAATT & ACTGCCGTGC & TTСTTCTCCT \\
\hline$\overline{\text { HQ149928 }}$ & 477 & CСAATACCAA АCGCCCCTGT & TCGTATGAGC & TGTTTTAATT & ACTGCCGTGC & ТTСТTсTсCT \\
\hline
\end{tabular}

MABO6

$\overline{\text { EF609452 }}$

$\overline{\text { FJ584082 }}$

GU805008

HQ149928

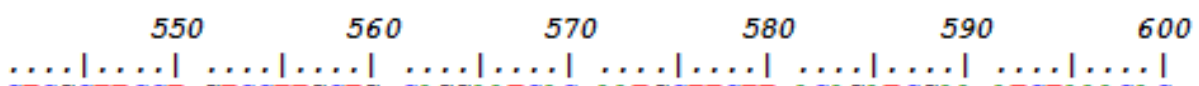

537 CTCGCTTCCT GTCCTTGCTG CAGGAATCAC AATGCTTCTT ACAGATCGAA ATCTAAACAC

541 CTCGCTCCCT GTCCTTGCTG CAGGAATCAC AATGCTTCTC ACAGATCGAA ATCTAAACAC

541 CTCGCTTCCT GTCCTCGCTG CAGGAATTAC AATGCTTCTT ACAGATCGAA ATCTAAACAC

541 CTCGCTTCCT GTCCTTGCTG CAGGAATCAC AATGCTTCTT ACAGATCGAA ATCTAAACAC

537 CTCGCTTCCT GTCCTTGCTG CAGGAATCAC AATGCTTCTC ACAGATCGAA ATCTAAACAC

MAB06

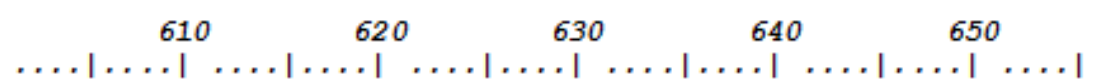

EF609452

597 TACCTTCTTT GACCCTGCAG GCGGAGGAGT CCCAATTCTT TATCAA-

601 TACCTTCTTT GACCCTGCAG GCGGAGGAGA CCCGATTCTC TATCAACACC TCTTC

601 TACTTTCTTT GACCCTGCAG GCGGAGGAGA CCCGATTCTT TACCAACACC TG

\begin{tabular}{lll}
$\overline{\text { GU805008 }}$ & 601 TACCTTCTTT GACCCTGCAG GCGGAGGAGA CCCAATTCTT TATCAACACC TC- \\
\hline HQ149928 & 597 TACCTTCTTC GACCCTGCAG GCGGAGGAGA CCCAATTCTC TATCAACACC TC
\end{tabular}

Figure 10 Amino acid composition of $S$. rubroviolaceus sample MAB06 of Graph showing hypothetical barcode profiling of $S$. rubroviolaceus of Parangipettai waters.

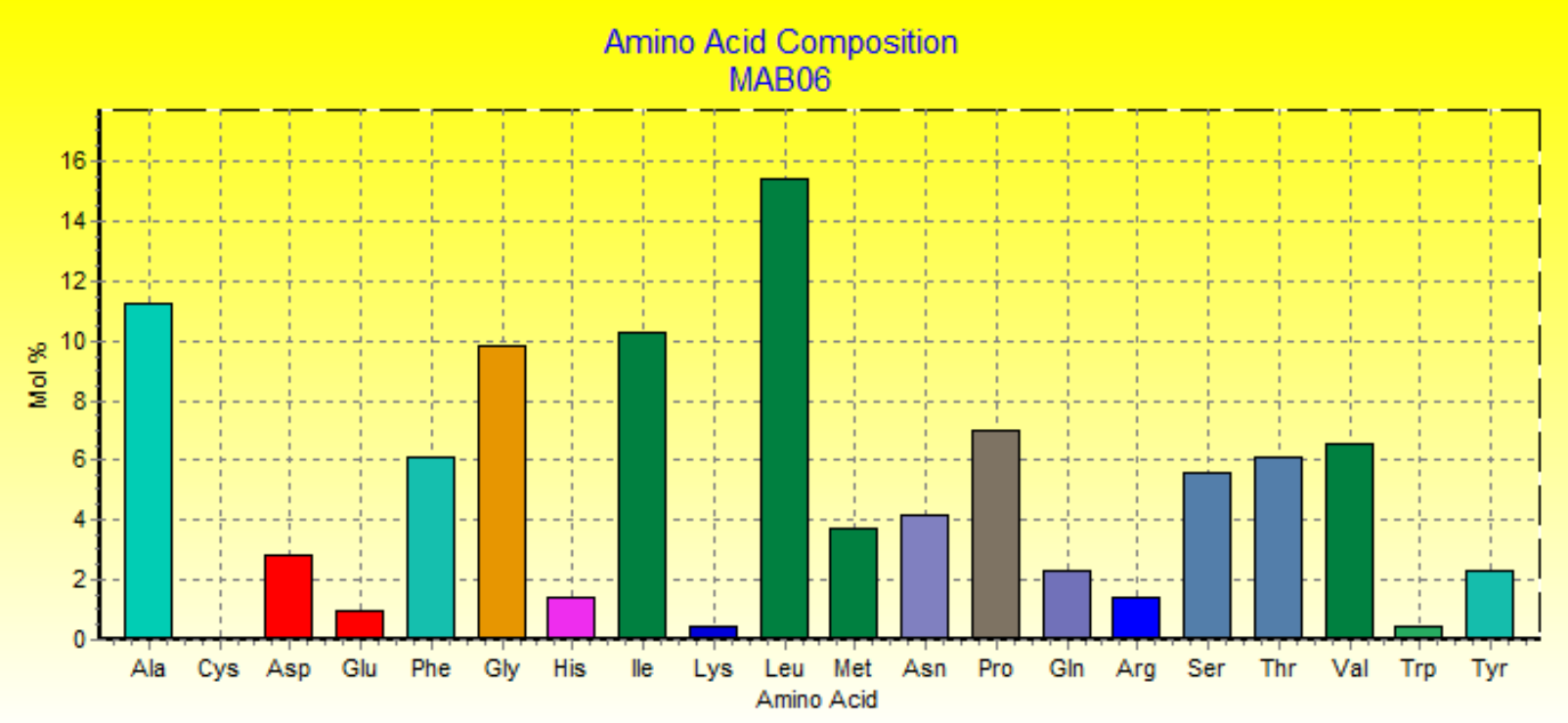


Figure 11 Helical wheel Diagram for Hypothetical Protein of sample MAB06

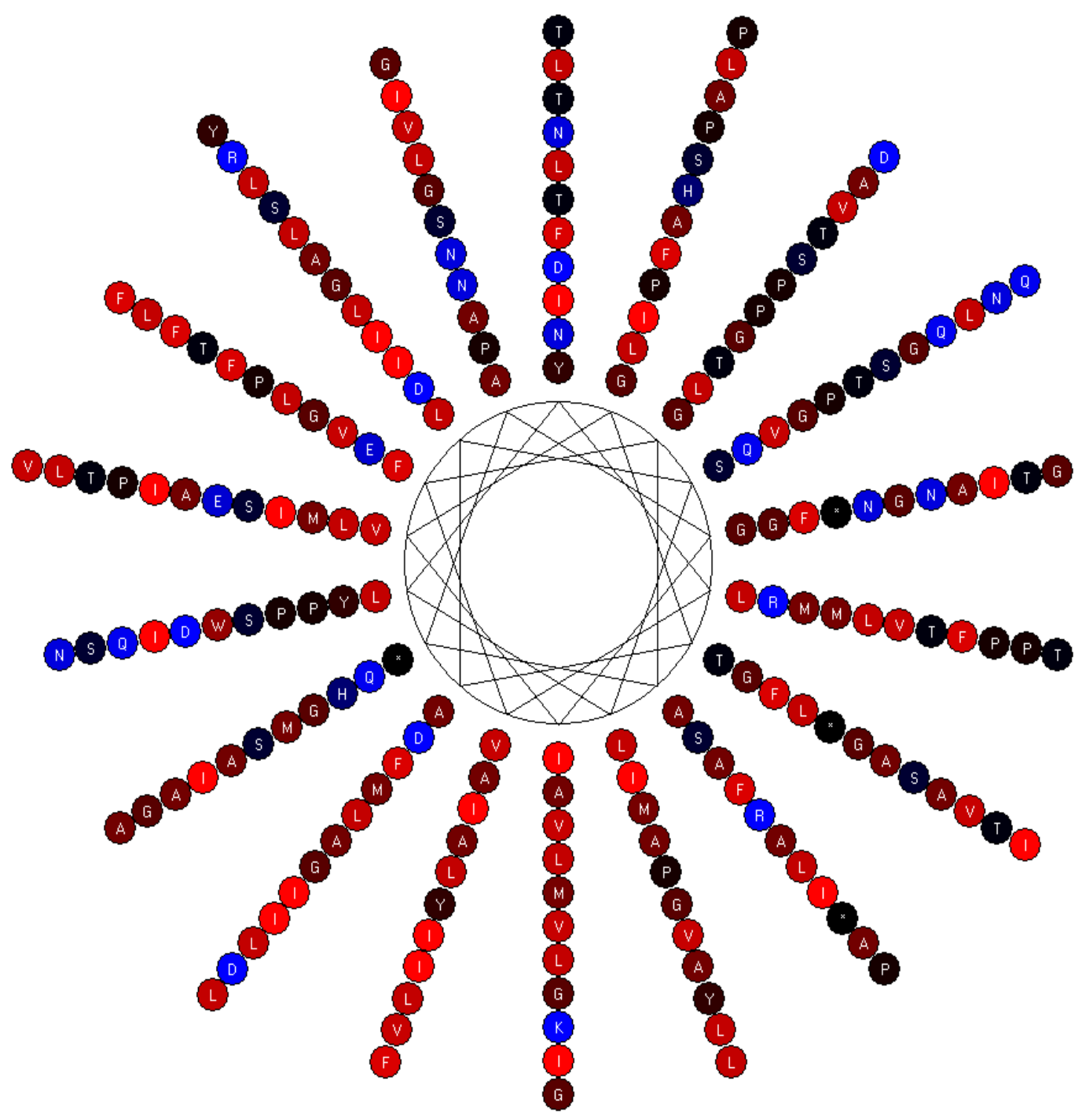


Figure 12 Evolutionary relationships of taxa by UPGMA Method

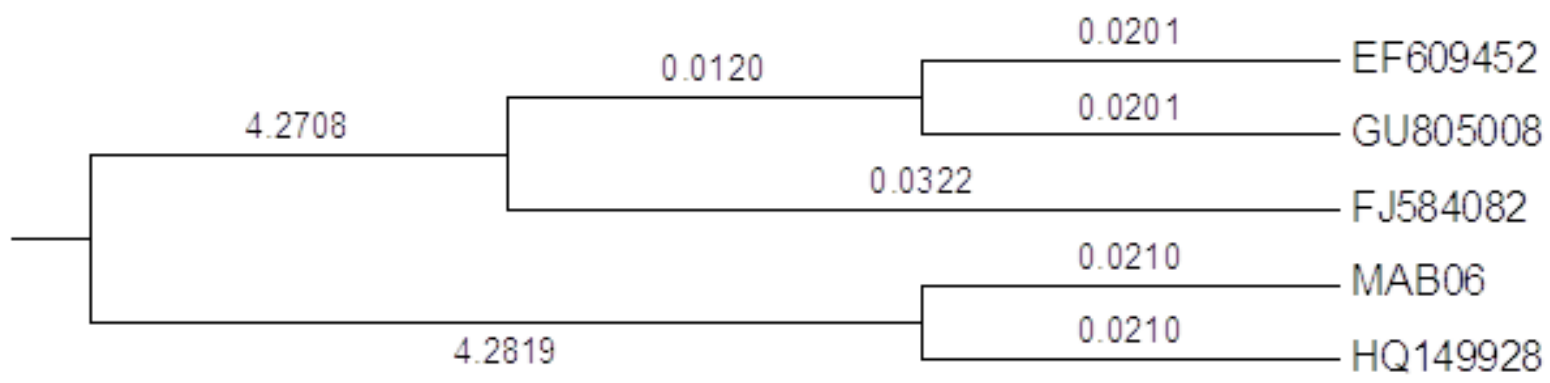

